\title{
Competition Authority in a Trap? A Few (Bitter) Words on Making Public Policy by Counteracting an Unfair Use of a Contractual Advantage in Agri-Food Sector in Poland ${ }^{1}$
}

\author{
Agata Jurkowska-Gomutka \\ University of Information Technology and Management, Poland \\ ajurkowska@wsiz.rzeszow.pl
}

\section{ABSTRACT}

A problem of counteracting bargaining powers of retailers, specially in agri-food sector, has been recently addressed by regulations in a few European countries but so far it has not been subject to academic considerations. A paper aims at finding rationales of granting administrative bodies with competences of interfering in contractual relationships between market players in reference to an abuse or misuse of bargaining power and to assess a possibility and probability of balancing public and private interests by administrative bodies applying regulations on counteracting an unfair use of a bargaining power. A point of reference for considerations is a Polish regulation dated from December 2016 - Act on Counteracting the Unfair Use of Contractual Advantage in the Trade in Agricultural and Food Products. In a lack of relevant case law a paper is based on a descriptive method of research as well as a method of conceptual analysis. A paper contests a correctness and rationality of selecting a competition authority as an enforcer of a discussed regulation. A competition authority seems to be caught in a trap of opposite (public and private) interests - an antitrust authority shall undertake an intervention in an interest of a private entity which in many situations may be seen as an intervention against public interest. The paper contributes to an ongoing discussion on EU's proposals for actions on eliminating imbalances between big retailing networks and food suppliers.

Keywords: agriculture, bargaining power, competition authority, contractual advantage, unfair practices

$J E L: K 20, L 14, L 40$

1 This article is a revised version of the paper entitled 'How much private interest in applying administrative law? Administrative bodies and their fight against unfair competition' presented at the EGPA conference, Milano, 30 August-1 September 2017. The EGPA contributions are not publicly available. 


\section{Introduction}

Competition policy is crucial for a proper functioning of a free market. Competition law as one of key instruments for enforcing competition policy. This area of law is featured with mixed public and private nature - antitrust law is considered as public (administrative) law whereas regulations on combating unfair practices belong to private (civil) law. Even if such a division of competition law in a broad sense has been well-established for many years in a great number of European countries, in recent years a few countries (among them Poland) decided to introduce a new type of regulation - the one on counteracting unfair use of bargaining power ${ }^{2}$ that in fact allows an administrative body (usually competition/antitrust and/or consumer authorities) to intervene into contractual relationships between private entities. The core of these regulations are conditions and prerequisites of a very civil nature that are not enforced, however, by civil courts, but by an administrative body. A peculiarity of these regulations lies in a fact that on their basis antitrust authority shall undertake an intervention in an interest of a private entity which in many situations may be seen as an intervention against public interest, what can be considered as "being trapped".

This new type of regulations brings a question on a reasonableness of public administration's interventions in individual relationships of entrepreneurs active on a market. This paper tries to find rationales of granting administrative bodies with competences of interfering in contractual relationships between market players in reference to an abuse or misuse of bargaining power. Providing that administrative authorities should still act only if a public interest is concerned, kind of natural is a question upon a necessity and a possibility of balancing properly public and private interests in a process of administrative proceedings based upon these new regulations. Because a main point of reference for considerations contained in this paper is a Polish regulation dated from 15 December 2016 - Act on Counteracting the Unfair Use of Contractual Advantage in the Trade in Agricultural and Food Products ${ }^{3}$, appointing a national competition authority (having a status of an administrative body) as an enforcer of this regulation, a paper focuses on weaknesses of introducing competences for counteracting unfair use of bargaining power by an administrative body responsible for an enforcement of competition policy.

A paper consists of five sections. The first one presents introductory remarks to the topic and thesis laying behind the article. The second section summarizes a methodology. The third section deals with a mixed nature of competition law, describes main ideas lying behind antitrust law, law against unfair competition and a new regulation on unfair use of bargaining power and presents rationalities for public interventions in case of antitrust law and a

2 Bargaining power is an economic rather than legal term, although it is used in the paper in order to describe imbalances between suppliers and purchasers that may result in a worse contractual position of one party. Other terms used to described this situation (also in this paper) are: contractual advantage (used in the official translation of the Polish regulation analyzed in this paper) or economic dependence (used e.g. in Portuguese Competition Act).

3 Polish Journal of Laws 2017, item 67. 
law on unfair use of a bargaining power. The forth section tries to prove that granting a competition authority with competences to interfere with contractual relationships means putting public administration in a trap that can influence negatively on a social reception of administrative law and functioning of public administration. Finally, conclusions based on previous considerations are presented.

\section{Methods}

The paper is based mainly on a descriptive method of research as well as a method of conceptual analysis. Because of a lack of relevant case law, the analysis focus mainly on legal texts and accompanying acts such as a draft proposal of a legal act and its justification and policy papers, with only few references to jurisprudence. References to foreign jurisdictions and literature are limited because of a very narrow scope of relevant sources containing analysis of the topic.

\section{Rationality for a Public Intervention By Competition Authority: Key Findings}

\subsection{Public and Private Regulations for Competition}

A term "competition law" covers legal regulations aimed at guaranteeing an existence of sound and fair competition which is a core of free market economy. A system of legal regulations dedicated to a protection of competition as a market mechanism is commonly established in a majority of European countries as a two-fold system consisting of public competition law, known as antitrust law, and private competition law, recognized as law against unfair competition. Both these areas constitute competition law in a broad sense, whereas antitrust law is usually considered as a competition law in a narrow sense. A demarcation line between public and private competition law lies in an interest protected by each of these regulations: antitrust law is oriented for securing competition as a market mechanism whereas private competition law aims at protecting an individual entrepreneur from anticompetitive (and thus unfair) behaviour of other market participants. Surely these regulations are not totally set apart because to a certain degree combating unfair practices somehow sustains a well-functioning and well-being of competition, but still an orientation for varied goals requires a totally different mechanisms, tools and institutional framework for enforcement of both types of regulations concerning a protection of competition and thus shaping a competition policy.

Antitrust law in Europe (not only in the EU Member States) patterns substantive competition rules concerning competition restricting practices settled in Art. 101 and Art. 102 TFEU. The Treaty provisions on restrictive practices are applied as long as a prohibited anticompetitive behaviour has an impact on a pattern of trade among EU Member States. Art. 101 on a prohibition of anti- 
competitive agreements and Art. 102 on a prohibition of an abuse of a dominant position can be enforced either by the European Commission (acting as the EU competition authority) or by national competition authorities (if the Treaty rules are applied simultaneously with national antitrust law). Even if there is no formal obligation of a harmonization of competition rules, national substantive competition rules in EU Member States (as well as countries in a process of an application for a membership) do not differ from their EU prototype, also procedural rules in antitrust proceedings are approximated to a high degree. Regarding state aid rules, Art. 107 TEU and its followers аге applied directly in EU Member States and there are no national rules in this area (except for certain technical provision concerning mainly monitoring and reporting duties on state aid). Due to such a system of a protection of competition throughout EU is pretty concise, based on a (possible) parallel application of the EU and national competition rules by public competition authorities. EU law does not settle any requirements upon a status of competition bodies, but in the absolute majority of EU Member States these bodies belong to a system of public administration (van de Gronden and de Vries, 2006, p. 32; Alves et al., 2015, p. 13; Zimmer, 2015, p. 255) and antitrust law is considered as a part of administrative law, sometimes also called: administrative economic law or public economic law). Sanctions for violating prohibitions of anticompetitive practices formally are administrative fines,but because of their potential big amount, they are treated as criminal sanctions due to standards of Art. 6(1) of the European Convention of Human Rights ${ }^{4}$ (Perroud, 2008; Błachnio-Parzych, 2012, p. 35).

Unlike in the US, public enforcement of antitrust law is dominant either in the EU or in its Member States, but it is complemented by private enforcement of antitrust law. The latter means that violations of antitrust rules (precisely: prohibitions of anticompetitive practices) can be sources of damages granted by civil courts on an individual demand after conducting a full "traditional" court proceeding ${ }^{5}$. In this dual system of an enforcement of antitrust law, a division of tasks is very clear: competition authorities protect public interest whereas courts provide measures protecting individual (justified) interests.

The characteristics of antitrust law should be supplemented by a concise, somehow juxtaposed, description of private competition law. Antitrust law concentrates on prohibiting market practices that can eliminate, distort or prevent competition as a necessary mechanism of a free market economy. Regulations on combating practices of unfair competition aim at eliminating market practices that do not have an impact on a whole market but they deteriorate a market position of competitors due to unfair behaviour, defined e.g. in Art. 3(1) of the Polish Act on Combating Unfair Competition" as "an ac-

4 See e.g. a judgment of ECtHR in case A. Menarini Diagnostics srl v. Italy, second section, 27 September 2011.

5 Private enforcement of antitrust law was much facilitated by an implementation of Directive 2014/104/EU of the European Parliament and of the Council of 26 November 2014 on certain rules governing actions for damages under national law for infringements of the competition law provisions of the Member States and of the European Union, OJ L 349, 5.12.2014, p. 1-19.

6 Act of 16 April 1993 on Combating Unfair Competition (consolidated text: Polish Journal of Laws 2003, No 153, item 1503, as amended). 
tion contrary to law and good practices, if it endangers or infringes interests of another entrepreneur or client". Unfair competition practices are, among others, constituted by misleading advertising ${ }^{7}$, unjustified discovering of business secrets or counterfeiting products. Only in regard to misleading (and comparative) advertising a national law on combating unfair competition implement EU directive, the biggest part of these regulations are just a result of domestic decisions (and legal traditions). Regulations on combating unfair competition stipulates measures of intervention typical for civil law - e.g. claims for repairing a damage, for discontinuation of unfair practice, claims in a case of unjustified enrichment (see Art. 18(1) the Polish Act on Combating Unfair Competition). Enforcers of these kinds of regulations are civil courts. Even if Art. 1 of the relevant Polish Act settles that the Act regulates issues of preventing and combating unfair competition "in public interest and in interests of entrepreneurs and clients", there is no doubt - in the context of the whole act - that this is an individual (private) interest that is predominantly protected by this regulation.

\subsection{Rationality of a Public Intervention on the Basis of Antitrust Law (With References to the Polish Act on Competition and Consumer Protection, 2007)}

A question on why public authorities intervene when competition is prevented, distorted or eliminated can be responded with a reference to economic and legal reasons. The doctrine of free market economy sees a competition as a necessary market mechanism, although competition is not an absolute value anymore - acceptability of state aid is the best example of this shift. What lies behind antitrust law that creates a legal and institutional framework for protecting competition is a public interest in preserving competition as a natural market force working for a total welfare. Certainly, public interest in antitrust law shall not be treated as a good way for a delivery of budget incomes from antitrust fines (even if because of a ceiling for fines at a level of $10 \%$ of total turnover or incomes, it is quite tempting) or a great measure to protect domestic entrepreneurs (specially national champions) from foreign competition or to protect state-owned companies from any external competitors. Public interest cannot be understood in this manner. Because of limited resources of competition authorities public interest in protecting competition as a market mechanism cannot be practically found in every single case of a distortion of competition - antitrust authorities have to select cases to intervene. Main goals of public bodies' activities are usually hardcore cartels which in fact are the most devastative for competition. Priorities of intervention are announced by antitrust authorities in multiannual programmes of competition policy.

7 In this regard the Polish Act on Combating Unfair Competition implements Council Directive 84/450/EEC of 10 September 1984 relating to the approximation of the laws, regulations and administrative provisions of the Member States concerning misleading advertising (OJ L 250 , 19.9.1984, p. 17 - 20) and Directive 97/55/EC of European Parliament and of the Council of 6 October 1997 amending Directive 84/450/EEC concerning misleading advertising so as to include comparative advertising (OJ L 290, 23.10.1997, p. 18 - 23). 
Public interest as a precondition for antitrust intervention exists in an enforcement of antitrust law either in direct or indirect manner. According to Art. 1(1) of the Polish Act on Competition and Consumer Protection ${ }^{8}$ it " (...) lays down the framework for development and protection of competition, and sets out the principles of actions to be undertaken, in the public interest, in order to protect the interests of undertakings and consumers". This provision directly mentions public interest as a sort of "metacondition" for applying substantive competition rules - if there is no public interest in antitrust intervention, the Act should not be applied. In further parts of the Competition and Consumer Protection Act a legislator identifies situations where a necessity for intervention - assessed from a perspective of a public interest - disappears. A lawmaker decided that public interest does not cover so called de minimis agreements (agreements of a minor importance) - Art. 7 of the Polish Competition Act exempts from a prohibition of anticompetitive restrictive practices agreements that do not include any hardcore restrictions of competition and which are concluded between entrepreneurs whose market shares are below certain thresholds ${ }^{9}$. In case of de minimisagreements a competition authority is released from a duty to conduct antitrust proceeding (de minimis rule is common in antitrust legislations, it is also applied by the European Commission ${ }^{19}$ ). A reason for a public intervention also disappears when limitation periods (of 5 years) for initiating an antitrust proceeding passes (Art. 93 of the Polish Competition Law).

Apart from these unique provisions, the Polish competition authority enjoys a very broad competence to shape a meaning of a metacondition of public interests, because according to Art. 47 of the Polish Competition Law antitrust proceedings are initiated solely on the own motion of a public enforcer, applications for starting an antitrust proceeding are not binding. What should be highly appreciated is a fact that the Polish competition authority in every antitrust decision refers to a prerequisite of public interest and explains in what way a particular case meets this condition. But still, if it gets a piece of information on a potential violation of law, the competition authority is not in any way obliged to provide explanations why a case is beyond public interest.

An interpretation of a concept (a notion) of public interest has a great impact upon a level and intensity of competition on relevant markets. A meaning of public interest can be delivered and shaped not only by an antitrust authority itself, but also by appealing bodies (in Poland, as in many other legislations: courts). A case law reflecting judges' positions on a public interest is vast. Over

8 Act of 16 February 2007 on Competition and Consumer Protection (consolidated text: Polish Journal of Laws 2017, items 229, 1089, 1132, as amended).

9 Agreements between entrepreneurs are exempted from a prohibition of anticompetitive agreements if market shares of parties to an agreement does not exceed $5 \%$ in case of horizontal agreements and $10 \%$ of vertical agreements. An agreement can benefit from an exemption only if it does not contain hardcore restrictions of competition.

10 Communication from the Commission - Notice on agreements of minor importance which do not appreciably restrict competition under Article 101(1) of the Treaty on the Functioning of the European Union (De Minimis Notice) (OJ C 291, 30.08.2014). 
more than 25 years of an application of antitrust law in Poland ${ }^{11}$ courts shifted from a quantitative to a qualitative concept of public interest. Treating a public interest in a quantitative dimension meant guaranteeing market conditions for an operation of as many competitors as possible. Public interest in a qualitative sense presumes that competition must be effective from a point of view of consumer (total) welfare, regardless a number of competitors (a welfare may not necessarily be provided by the highest possible number of entrepreneurs active on a market). A settled interpretation of public interest as a reason for antitrust intervention by public authorities is concisely described in the following statement of the Warsaw Court of Appeals dated from 17.12.2010 (VI Aca 427/10): “(...) Preventing a common economic damage caused to consumer (or increasing its size) shall be treated as a value constituting a public interest. (...) A violation of a interest of any individual is even not necessary to apply instruments of intervention regulated in the Act". Indeed, sometimes an activity of a public enforcer brings some benefits to individuals (because of a public intervention an entrepreneur whose interest was touched by anticompetitive practices does not need to stand up to a court with a claim for giving up a prohibited practice).

\subsection{Regulations Against Unfair Use of a Contractual Advantage}

An economic development resulted in a growing number of chains of hyperand supermarkets and their great buying power in many European countries. Big retailing networks became very powerful market players who could have abuse their economic positions in relationships with their suppliers, especially with SMEs. Undoubtedly, unfair treatment of suppliers happened and these practices could not have been caught by Art. 102 TFEU (a prohibition of an abuse of a dominant position) or its national counterparts, because retailing networks do not have a dominant position on a relevant (European or domestic) market (Stefanelli and Marsden, 2012, p. 3). Therefore the European Commission prepared the thorough analysis of a distribution chains of food products which showed that some practices of traders should be eliminated (DG Internal Market, 2014; OECD, 2014). However, the European Commission itself so far has not decided to introduce any binding law (regulations or directives) against unfair use of a bargaining power of purchasers, but it adopted in 2014 the Communication on tackling unfair trading practices (UTPs) in the business-to-business food supply chain ${ }^{12}$ and in 2016 addressed the report on unfair business-to-business trading practices in the food supply chain to the European Parliament and the Council ${ }^{13}$. But a debate on EU legal framework

11 The first antitrust regulation designed for a market economy was adopted in Poland in February 1990.

12 Communication from the Commission to the European Parliament, the Council, the European Economic and Social Committee and the Committee of the Regions - Tackling unfair trading practices in the business-to-business food supply chain, Strasbourg, 15.7.2014, COM(2014) 472 final.

13 Report from the Commission to the European Parliament and the Council on unfair businessto-business trading practices in the food supply chain, Brussels, 29.1.2016, COM(2016) 32 final. 
for unfair practices in food retaining is still on, heated up by the European Parliament ${ }^{14}$ and supported by the European Council ${ }^{15}$.

In a few countries national traders decided to adopt a national code of conduct and thus grounds for lawmakers' intervention disappeared. In other countries, indeed, sales networks did not succeed in cooperating so legislators decided to act. Certainly, there was a problem with abusing a bargaining power by some market players - because of the fact that usually none of hyper- or supermarkets chain has a dominant position on a national market, practices against suppliers could not have been caught by a prohibition of an abuse of a dominant position (which is included in "traditional" antitrust law). Despite some minor differences in conditions or sanctions, a philosophy of legislator's intervention remains the same: an administrative body is provided with a competence to stop or to amend contracts between individual entrepreneurs if circumstances show that a bargaining power was unfairly used by a chain. An expiry or a change of a contract is not the only measure of an intervention, an enforcer is usually in charge to impose a fine on an infringer. It must be added here that usually all these abusive, unfair practices were undertaken in relations with food suppliers so regulations are often limited to an agricultural and food sector.

Regulations of this kind were adopted e.g. in Poland, Italy, Hungary and Romania.

\subsection{Rationality of a Public Intervention on the Basis of Law Against Unfair Use of Bargaining Power (With References to the Polish Act on Counteracting the Unfair Use of Contractual Advantage in the Trade in Agricultural and Food Products, 2016)}

Equality of parties in civil law-based relations, guaranteed as one of fundamental values in civil codes, in reality is strongly modified by market (economic) and social conditions. Entities holding a certain level of market power - which can result from e.g. a volume of purchase/sales or localization - they enjoy a total discretion in selecting contractors (from a great number of) and therefore they may be tempted to abuse their bargaining power. As pointed above such a situation may occur specially in a retail sector, in relations between hyperand supermarkets chains and their suppliers, mainly suppliers of food products. This inequality of market positions and a bargaining advantage of retail chains (quite often companies of foreign origins) versus a "handicapped" position of suppliers (usually domestic companies, farmers or their associations) created a promising political (even populist in some cases) potential.

Regulations on combating unfair practices resulting from a bargaining position are generally based on a prerequisite of a public interest - an interven-

14 See European Parliament Resolution of 7 June 2016 on unfair trading practices in the food supply chain (2015/2065(INI)).

15 Council conclusions of 12 December 2016, Strengthening farmers' position in the food supply chain and tackling unfair trading practices. 
tion of an administrative body is initiated if a public interest is somehow damaged. Art. 1 of the Polish Act on Counteracting the Unfair Use of Contractual Advantage bears a resemblance to Art. 1 of the Competition and Consumer Protection Act claiming that "Act establishes rules and procedures for counteracting, in order to protect public interest, practices that unfairly use a contractual advantage (....)". Both provisions calls a public interest as a condition for an administrative interference, both regulations are enforced by the same specialized administrative authority which is the President of Office of Competition and Consumer Protection. But does a public interest mean the same in both regulations? A coherence of a legal system and a coherence of a system of public administration would require the same interpretation of this concept. If a lawmaker grants a competition authority with competences to enforce the new regulation on an unfair abuse of a contractual advantage, it is reasonable to expect that the idea behind it was an implementation of the same goal, i.e. protecting a public interest in the same dimension (as it is clear that an interpretation of a public interest can vary depending on the content of a certain regulation and its enforcement system). However, a meaning of a concept of a public interest - that must be protected by the Polish competition authority - is totally different in the context of the Competition and Consumer Protection Act (where public interest means protecting competition as a mechanism of market economy) and the Act on Counteracting the Unfair Use of Contractual Advantage. The latter refers to a public interest but, as it can be read in a governmental preface to the draft Act, mainly in a context of food safety. In the preface we can read that "the draft proposal aims at eliminating unfair practices from a distribution chain of supplies of agricultural and food products. This area of economic activity is linked to a food safety of the state so it has also a social dimension"16. Then a government claims that food safety is a part of a national safety so it is "significantly important" to prevent a negative influence of contractual relations on a food safety of Poland. A danger for a food safety is reflected in by a fact that purchasers' pressure on a level of prices imposed by suppliers can result in a limitation of production or its absolute abolishment or in a deterioration of a quality of food. Additionally, the government affirms that because of unfair practices in trading agricultural and food products a financial situation of food producers is weakened what results in decreasing food quality and investing resources as well as in limiting their innovativeness. What appears as a final justification of an administrative intervention into a freedom of contract is a particular interest of a particular group: food producers. Even if the Act theoretically refers to unfair practices that can be undertaken by both parties - purchasers and suppliers, the justification for the Act tells almost exclusively about unfairness of purchasers, identifying them mostly as chains of hyper- or supermarkets, even if a distribution chain of food (potential "unfair practitioners") is much more complex ${ }^{17}$. In the context of a competition authority's activities public inter-

16 Draft Proposal, p. 1. At: <http://www.sejm.gov.pl/Sejm8.nsf/druk.xsp?nr=790> (accessed 25 July 2017).

17 Four organisations of distributors and retailers (Polish Chamber of Commerce, Main Council of Associations of Commerce and Services, Polish Organization of Commerce and Distribution, Forum of Polish Trade) consider the Act on Counteracting the Unfair Use of Contractual 
est can be easily associated with consumers' interest. Astonishingly, consumers were mentioned in a preface to the draft proposal only twice, certainly, the regulation is not consumer-oriented at all. The draft proposal did not say a word about a possible increase of food prices for consumers as a result of a public interference with contractual relationships.

\section{Administrative Body Responsible for Counteracting an Unfair Use of a Contractual Advantage - In a Trap of Contrary Interests}

In the Polish case where a competition authority was selected as an enforcer of the Act on Counteracting the Unfair Use of Contractual Advantage in the Trade in Agricultural and Food Products it needs to be observed that an administrative body was caught in a trap of interests (Chauve at al., 2014, p. 304). And this trap is even double-level.

The first level covers to a contradiction within a sole concept of a public interest on the basis of the Competition and Consumer Protection Act and on the grounds of the Act on Counteracting the Unfair Use of Contractual Advantage. In the first case a public interest means protecting competition (market rivalry), in the second - a public interest is condensed to a food safety. A problem arises when competition authority's intervention for a sake of a food safety is... anticompetitive. Let us imagine that a supermarket chain gave a notice on an expiry of a multiannual contract to a producer of apples. A notice was given in a total accordance with rules prescribed in a contract, an expiry of a contract will be completed in an appropriate period. A reason for finishing a cooperation is a lower price of apples offered by a new contractor. A decision of a supermarket chain seems rational. This is generally how a competition works: if you are offered a cheaper product that you can sell at the same price as a product bought at a bigger price or you can sell more products of this kind because you can offer a lower price to consumers, you probably go for it. It needs to be underlined, however, that in contractual relationships a price is not the only factor considered in business decisions. Does the competition authority start a proceeding against a supermarket chain from this example on the basis of the Act on Counteracting the Unfair Use of Contractual Advantage? It is highly probable - formal prerequisites for starting such a proceeding, prescribed in the Act, do allow for it. Does the competition authority impose a fine on a supermarket chain? Again, it is highly probable (a fine up to $3 \%$ of a total turnover of an infringer gained in a previous year). Initiating the proceeding and adopting a decision will be totally correct in the light of the Act on Counteracting the Unfair Use of the Contractual Advantage, but it may be considered as a decision stopping a development of competition what in fact is contrary to a competition authority's task in the light of Competition and Consumer Protection Act. Isn't it a real trap leading to a schizophrenia of this administrative body? A similar problem can be met in all countries who

Advantage as "asymmetric". <http://biznes.onet.pl/wiadomosci/handel/wspolny-glos-handluustawa-o-nieuczciwych-praktykach-jest-asymetryczna/eg7trc> (accessed 25 July 2017). 
have made competition authorities (instead of e.g. Ministry of Agriculture) responsible for an implementation of this aspect of public policy, e.g. Czech Republic (P. Frischmann, V. Šmejkal , 2016, p. 227).

The second dimension of a trap is much connected with considerations presented in the section III above, a public interest in the Act on Counteracting the Unfair Use of Contractual Advantage have only a little in common with public interest as a reason for administrative intervention in antitrust cases, even if a public interest is expressed literally in Art. 1 of the Act and even if in the preface to draft proposal guaranteeing of a food safety is declared as a foreground goal. It is even not an public intervention in consumers' interests. The administrative authority intervenes for a sake of private interests. This "privatization" of activities of public administration in a process of an enforcement of the Act on Counteracting the Unfair Use of Contractual Advantage is indirectly confirmed by a legal definition of an unfair use of a contractual advantage. Due to Art. 7(2) of the regulation "Using a contractual advantage is unfair if it is contrary to good practices and it endangers a significant interest of the other party or if it infringes such an interest". In the context of this definition a precondition for a competition authority's intervention is a real or potential damage caused to an individual entrepreneur. Here a question arises if the competition authority has to intervene in all situations when private interests are violated or - at least - endangered. By an analogy with the Competition and Consumer Protection Act it shall be pointed that a public interest mentioned in Art. 1 of the Act is a selection criteria, but does it work in this manner in a case of the Act on Counteracting the Unfair Use of Contractual Advantage? I profoundly doubt. In antitrust law public interest means protecting a competition in danger, regardless individual damages, whereas on the basis of the Act on Counteracting the Unfair Use of Contractual Advantage a violation of an individual (particular) interest is a necessary element of a violation of law, so an entrepreneur whose interests were infringed can reasonably expect an intervention of the President of Competition and Consumer Protection. This expectation is justified because by introducing a threshold of 50,000 PLN (ca. 11,900 EUR) of a combined turnover of parties to a contested contract as an entrance condition for an intervention of an administrative organ. Establishing such a threshold in Art. 2 point 1 allows for a presumption that in cases where this quantitative condition is met and a practice meets qualitative conditions from a definition of an unfair use of a contractual advantage, the public administration intervenes. It is rather doubtful if a food safety - declared as a goal of the regulation - can be endangered by a single case of abusing bargaining (contractual) power. The public intervention for a sake of public interest would be justified if violations of a prohibition of an unfair use of a bargaining power were numerous. But the Act on Counteracting the Unfair Use of Contractual Advantage does not contain any condition like that for administrative activities. The Act leaves a room for a discretion of the competition authority to intervene, however if prerequisites of a prohibition are described in such an individualized manner entrepreneurs has all the right to expect that they will be supported by public administration, especially if a public intervention has a direct and immediate effect on their market posi- 
tion. According to Art. 26(2) of the Act an administrative body is obliged to impose a duty on an infringer to discontinue a prohibited practice (what in reality means e.g. a continuance of a contractual relationship or a change in a contract, regardless a negative business result for one party). On the grounds of Art. 27(1) of the Act an infringer can be also obliged to implement commitments defined by the competition authority - if an infringer agrees for imposing the duties (e.g. a change in a contract), it can avoid a decision declaring an infringement and it can avoid a fine. No matter what decision (a commitment decision or an "infringement decision") is taken, an individual entrepreneur benefits from it. However, the regulation lacks any procedures allowing for contesting an administrative body's decision on a non-initiation of a proceeding so individuals' demands for a public intervention are prevented. A (potential) victim of an unfair practice is entitled to make a notice to the competition authority in case of a suspicion of an unfair practice (Art. 11(1) and (2)), the administrative organ is only obliged to provide information on its respond to this notice, in fact to inform if a proceeding is initiated or not (Art. 11(3)). Summing up, the administrative body's discretion within a decision on initiating (or not) an administrative proceeding seems to be the only mechanism for balancing public and private interests in an administrative intervention. Administrative discretion seems to be a very weak instrument regarding a fact that a public intervention on the basis of the Polish Act on Counteracting the Unfair Use of Contractual Advantage goes deeply in a sphere of fundamental values such as economic freedom and freedom of contract.

\section{Conclusions}

By the Polish Act on Counteracting the Unfair Use of Contractual Advantage a lawmaker obliged a public administration to interfere with contractual relations (or even wider: with economic freedom), justifying it by a public interest, even if in reality effects of this interference are visible foremostly in an area of private legal and economic interests (presumingly, in a scheme: benefits for one party, costs for the other), with no significant benefit for a public interest. Administrative body is just granted with competences that are normally reserved for civil courts (what in my personal view is worth criticizing).

The analyzed regulation lacks any instruments allowing the administrative body for balancing private and public interests in order to assess a necessity and effectiveness of public intervention in a particular case. Even if the administrative body is not obliged to initiate an administrative proceeding in any case, a room for a broad discretion was left here, a definition of a violation of a prohibition of an unfair use of contractual advantage, referring to a real or potential damage to a particular entrepreneur in fact requires an intervention in very individualized cases. On the other hand there is no mechanism to demand an intervention from an administrative body. The lawmaker seems to have stopped half-way. Such an approach puts the administrative organ in a very difficult situation - interventions in all particular cases probably will be not useful from a perspective of protecting public interest (food safety), but a lack of intervention in individual cases where qualitative and quantitative con- 
ditions are met will certainly dramatically decrease citizens' trust in public administration (which belongs to fundamental principles of administrative law, also according to the Art. 8 of the Polish Code of Administrative Conduct $^{18}$ ).

Even if an intervention of a competition authority into contractual relationships of entrepreneurs may be considered as justified, reasons for this intervention are linked to food safety rather than to sustaining and developing competition. If so, this is not a competition authority that should be obliged to enforce the new Act - it should be done by an organ of public administration in charge of food and agricultural sector. Otherwise, competition authority seems to face schizophrenia when some of its proceedings are aimed at developing competition, whereas the others are oriented for interfering with legally-shaped market relationships often stemmed from a sound competition. This must have a (rather negative) impact upon effectiveness of public administration within its task in protecting market mechanisms. A solution of this dilemma is to move regulations on a contractual advantage in food supply chains out of (public) competition law (antitrust law) and transfer it into agricultural law - it would guarantee at least a cohesion of a concept of public interest in applying a certain branch of administrative law - protecting farmers' interest on the grounds of agricultural law seems to be much more understandable than "indirect" protection of these interests in antitrust law ${ }^{19}$.

The Polish Act on Counteracting the Unfair Use of Contractual Advantage proves a growing impact of private interests in a process of making administrative law and applying administrative (at least formally) regulations by administrative bodies. This is not solely a case of Poland, but also of other countries that decided to adopt law on counteracting/combating a bargaining power (contractual advantages) in agricultural and food sector. Some countries, like Germany ${ }^{20}$ and Portugal, used to combat an abuse of bargaining power (economic dependency) in general, regardless a sector, straight on the basis of their antitrust provisions (although enforcement of the provisions of German Gesetz gegen Wettbewerbsbeschränkungen in agrifood sector so far has not been successful (Künstner, 2015, p. 1093; Łyszczarz, 2017, p. 141). A specific case is Great Britain (probably the most successful in counteracting unfair practices in food sector) that in 2009 - under auspices of the Department of Business, Energy and Industrial Strategy - adopted Groceries Supply Code of Practice that since 2013 has been implemented by a specialized body: Grocery Code Adjudicator. A few countries (e.g. Belgium, Finland, the Netherlands), however, did not decide for such an intervention - in this countries code of conducts took a place of hard regulations. Selfregulation may be the best way to avoid a trap of interests, however, the EU

18 Art. 8 of the Polish Code of Administrative Procedure: "Public administration bodies are required to conduct proceedings in such a way as to increase the trust of citizens in the State bodies and public awareness and appreciation of the law".

19 Currently (January 2018), works upon EU-wide legislative framework upon a functioning of food supply chains are headed at the European Commission by DG Agriculture (in cooperation with DG Comp).

$20 \S 20(2)$ in connection to § 19(2)(5) of Gesetz gegen Wettbewerbsbeschränkungen. 
debate on unfair practices in food supply chains seems to go in a completely opposite direction - a tension for adopting hard law seems to be very strong, predominantly from the European Parliament, although a scope and a type of regulations are still under discussion the EU level ${ }^{21}$.

National laws on the basis of which (as in Poland) competition authorities are responsible for combating unfair practices in an agri-food sector, acting to some extant against a fundamental value that must be protected by competition authority, surely constitute a "conflictual" administrative law (Napolitano, 2014, p. 357), it also belongs to a "new administrative law" (Cassese, 2012, p. 603), but is it a proper direction of a development of administrative law as such and this particular area of regulation? A problem of imbalanced relations between food suppliers and purchasers is of great importance although it surely requires a more strategic approach than adopting a regulation that uses public law instruments to protect individual interest, with no future vision on an impact on this regulation upon counteracting a problem (food safety) in the bigger scale.

21 On 25 July 2017 the European Commission published "policy options" for tackling unfair practices in agri-food sector: Inception Impact Assessment. Initiative to improve the food supply chain. Ref. Ares(2017)3735471 - 25.7.2017. <http://ec.europa.eu/info/law/better-regulation/ initiatives/ares-2017-3735471_en> (accessed 28 July 2017). 


\section{References}

Act of 15 December 2016 - Act on Counteracting the Unfair Use of Contractual Advantage in the Trade in Agricultural and Food Products (Polish Journal of Laws 2017, item 67).

Act of 16 February 2007 on Competition and Consumer Protection (consolidated text: Polish Journal of Laws 2017, items 229, 1089, 1132, as amended).

Act of 16 April 1993 on Combating Unfair Competition (consolidated text: Polish Journal of Laws 2003 No 153, item 1503, as amended).

Alves, S., Capiau, J. and Sinclair, A. (2015). Principles for the Independence of Competition Authorities. Competition Law International, 11(1), pp. 13-27.

Btachnio-Parzych, A. (2012). The Nature of Responsibility of an Undertaking in Antitrust Proceedings and the Concept of 'Criminal Charge' in the Jurisprudence of the European Court of Human Rights. Yearbook of Antitrust and Regulatory Studies, 5(6), pp. 35-55.

Cassese, S. (2012). New paths for administrative law: A manifesto. International Journal of Constitutional Law 2012, 10(3), pp. 603-613.

Chauve, P., Parera, A. and Renckens, A. (2014). Agriculture, Food and Competition Law: Moving the Borders. Journal of European Competition Law and Practice, 5(5), pp. 304-313.

Communication from the Commission to the European Parliament, the Council, the European Economic and Social Committee and the Committee of the Regions - Tackling unfair trading practices in the business-to-business food supply chain, Strasbourg, 15.7.2014, COM(2014) 472 final.

Communication from the Commission - Notice on agreements of minor importance which do not appreciably restrict competition under Article 101(1) of the Treaty on the Functioning of the European Union (De Minimis Notice) (OJ C 291, 30.08.2014).

Council conclusions of 12 December 2016, Strengthening farmers' position in the food supply chain and tackling unfair trading practices.

Council Directive 84/450/EEC of 10 September 1984 relating to the approximation of the laws, regulations and administrative provisions of the Member States concerning misleading advertising (OJ L 250, 19.9.1984, pp. 17-20).

Directive 2014/104/EU of the European Parliament and of the Council of 26 November 2014 on certain rules governing actions for damages under national law for infringements of the competition law provisions of the Member States and of the European Union (OJ L 349, 5.12.2014, pp. 1-19).

Directive 97/55/EC of European Parliament and of the Council of 6 October 1997 amending Directive 84/450/EEC concerning misleading advertising so as to include comparative advertising (OJ L 290, 23.10.1997, pp. 18-23).

EC Final Report, DG Internal Market, "Study on the legal framework covering business-to-business unfair trading practices in the retail supply chain", DG MARKT/2012/049/E, February 2014.

European Commission (2017). Inception Impact Assessment. Initiative to improve the food supply chain. Ref. Ares(2017)3735471 - 25.7.2017. At: <http:// ec.europa.eu/info/law/better-regulation/initiatives/ares-2017-3735471_en> (accessed 28 July 2017).

European Parliament Resolution of 7 June 2016 on unfair trading practices in the food supply chain (2015/2065(INI)). 
Frischmann, P. and Šmejkal, V. (2016). 2016 Amendment of the Czech Significant Market Power Act of 2009. Yearbook of Antitrust and Regulatory Studies, 9(14), pp. 227-235.

Judgment of European Court of Human Rights, 27 September 2011, A. Menarini Diagnostics srl v. Italy (no. 43509/08).

Künstner, K. (2015). Die Anwendung des kartellrechtlichen Anzapfverbots im Lebensmitteleinzelhandel und darüber hinaus. Wirtschaft und Wettbewerb, 11, pp. 1093-1104.

Łyszczarz, W. (2017). Zwalczanie nadużywania przewagi kontraktowej w handlu detalicznym produktami spożywczymi w Niemczech - przegląd. Internetowy Kwartalnik Antymonopolowy i Regulacyjny, 6(1), pp. 141-157.

Napolitano, G. (2014). Conflicts and strategies in administrative law. International Journal of Constitutional Law, 12(2), pp. 357-369.

OECD (2014), Competition Issues in the Food Chain Industry, DAF/ $\operatorname{COMP}(2014) 16$.

Perroud, T. (2008). The impact of Article 6(1) ECHR on competition law enforcement: A comparison between France and the United Kingdom. Global Antitrust Review, 1, pp. 48-68.

Report from the Commission to the European Parliament and the Council on unfair business-to-business trading practices in the food supply chain, Brussels, 29.1.2016, $\operatorname{COM}(2016) 32$ final.

Stefanelli, J. and Marsden, P. (2012). Models of Enforcement in Europe for Relations in the Food Supply Chain, British Institute of International and Comparative Law.

Van de Gronden, J. W. and de Vries, S. A. (2006). Independent competition authorities in the EU. Utrecht Law Review, 2(1), pp. 32-66;

Zimmer, D. (2015). Competition law enforcement: administrative versus judicial systems. In P. Nihoul and T. Skoczny, eds., Procedural Fairness in Competition Proceedings, Edward Elgar Publishing, pp. 255-264. 